\title{
How the Coach-Created Empowering and Disempowering Motivational Climate Predict Prosocial and Antisocial Behavior of the Athlete?
}

\author{
Enrika Kromerova-Dubinskiene \\ Lithuanian Sports University, Lithuania
}

\begin{abstract}
.
Some researchers note that some athletes exhibit respectable, moral behavior such as fair play, compliance with rules, respect for the opponent and teammate (Siedentop, Hastie \& van der Mars, 2004), while others (Lee, Whitehead, Ntoumanis \& Hatzigeorgiadis, 2008) reveals ethically unacceptable behavior by athletes: violence, impersonation, and other acts that physically or psychologically harm competitors. Such duality can be explained by the influence of the sports environment. The sports environment offers many opportunities for young athletes to develop life skills (time management, problem solving) and to develop ethical values perseverance and integrity (Camiré \& Trudel, 2010). However, it is believed that competitionoriented sporting activities can also promote antisocial behavior because sport is based on competition, relatively moral judgment, influenced by formal or informal rules (Stephens \& Bredemeier, 1996; Shields \& Bredemeier, 1995). It is believed that the motivational climate created by the coach, as the key person, affects athletes not only on the field but also in other areas of life. Although the direct influence of a coach on athletes is usually limited, they spend a great deal of time with youth in an sport environment, creating an atmosphere that studies have shown to influence athletes, beliefs, feeling and prosocial behavior (Duda, 2013; GanoOverway, 2013; Rutten et al., 2011). The main purpose of this study was to investigate how does the empowering and disempowering climate of a coach influence athletes' behavior? It was hypothesized that coach created empowering motivational climate would be positively predict prosocial behavior of the athlete, while disempowering climate positively predict antisocial behavior.
\end{abstract}

Keywords: adolescent athletes, coaching style, sport. 


\section{Description of participants}

The sample $(\mathrm{N}=385)$ comprised 227 males and 158 females aged between 13 and 16 years old $(M=14.2 ; S D=1.11)$. The athletes represented basketball $(\mathrm{n}=151)$, football $(\mathrm{n}=55)$, volleyball $(\mathrm{n}=108)$, and track and field $(\mathrm{n}=71)$ sports. The mean number of seasons the participants had been playing their current sport was $3.95(S D=2.44)$.

\section{Measurements}

Perceptions of the coach-created motivational climate (Appleton et al., 2016). Participants subsequently rated the 34 items on a 5-point scale (e.g., $1=$ absolutely unclear, $5=$ completely clear) to determine the extent to which the translation was understood by junior sport participants. Participants responded to 17 items assessing their perception of empowering features of the coach-created motivational climate and 17 items assessing their perceptions of disempowering features of the coach-created motivational climate.

Prosocial and antisocial behaviour in sport (Kavussanu \& Boardley, 2009). Participants were presented with 20 items and were asked to report how often they had engaged in each behaviour this season on a Likert scale anchored by $1=$ never and $5=$ very often. The PABSS consists of four subscales that measure antisocial behaviour toward opponents and toward, and prosocial behaviour toward opponents and teammates.

\section{Results}

It was conducted two regression analyses to test whether empowering and disempowering climate predicted the moral behaviour of athletes. The results of the analyses (Table 1) indicated that empowering climate was a positive predictor for prosocial behaviour of athletes. Disempowering climate emerged as a positive predictor for antisocial behaviour.

\begin{tabular}{|c|c|c|c|c|c|}
\hline Variable & $\mathrm{B}$ & $\begin{array}{c}B \\
95 \\
\% \\
\text { CI }\end{array}$ & $\beta$ & $t$ & $\mathrm{~A} R^{2}$ \\
\hline \multicolumn{6}{|l|}{$\begin{array}{l}\text { Prosocial } \\
\text { behaviour }\end{array}$} \\
\hline $\begin{array}{l}\text { Empowerin } \\
\text { g climate }\end{array}$ & $\begin{array}{l}0 . \\
4 \\
3\end{array}$ & $\begin{array}{c}0.2 \\
7< \\
>0 . \\
59\end{array}$ & $\begin{array}{l}0 . \\
2 \\
6\end{array}$ & $\begin{array}{l}5.17 \\
* * *\end{array}$ & \\
\hline \multirow{5}{*}{$\begin{array}{l}\text { Disempowe } \\
\text { ring climate }\end{array}$} & & - & & $n s$ & \\
\hline & 0. & 0.0 & 0. & & \\
\hline & 0 & $4<$ & 0 & & \\
\hline & 7 & $>0$ & 6 & & \\
\hline & & 19 & & & \\
\hline
\end{tabular}




\section{Antisocial}

behaviour

Empowerin

ns

g climate

0 .

\section{1}

0

$\begin{array}{ll}4< & 0 . \\ >0 . & 0 \\ 09 & 2\end{array}$

Disempowe

0.

0.1

ring climate

0.

Table 1. Hierarchical regression of empowering and disempowering motivational climate predicting athletes' moral behaviour in sport.

Note. $\mathrm{A} R^{2}=\mathrm{R}^{2}$ unique to each step, ${ }^{* * *} p<.001, \mathrm{CI}=$ confidence interval, $n s=$ not significant.

\section{Discussion and conclusions}

The findings of the study are in line with previous research concerning the coach-created motivational climate and athletes' moral behaviour that has shown that a coach autonomysupport, as empowering climate form, predict prosocial behavior, while controlling coaching, as disempowering climate form, predicted higher levels of moral disengagement and antisocial behaviour towards opponents and teammates as well (Hodge \& Gucciardi, 2011). Other studies show positive links between mastery climate with prosocial behavior with teammates and a negative relationship with antisocial behavior with both team and opponents (Stanger, Backhouse, Jennings, \& McKenna, 2018) and positive assosiations between performance climate and antisocial behavior towards opponents (Boardley \& Kavussanu, 2009; Sage \& Kavussanu, 2008) and teammates (Boardley \& Kavussanu, 2009).

In conclusion, the coach-created empowering motivational climate predicts prosocial behavior of the athlete, while disempowering climate - antisocial behavior.

\section{References}

1. Appleton, P. R., Ntoumanis, N., Quested, E., Viladrich, C., \& Duda, J. L. (2016). Initial validation of the coach-created Empowering and Disempowering Motivational Climate 


\title{
World Conference on Teaching and Education
}

\author{
18-20 October, 2019 \\ Budapest, Hungary
}

Questionnaire (EDMCQ-C). Psychology of Sport and Exercise, 22, 53-65. doi:10.1016/j.psychsport.2015.05.008

2. Boardley, I., \& Kavussanu, M. (2009). The influence of social variables and moral disengagement on prosocial and antisocial behaviours in field hockey and netball. Journal of Sports Science, 27, 843-854.

3. Camiré, M., \& Trudel, P. (2010). High school athletes' perspectives on character development through sport participation. Physical Education and Sport Pedagogy, 15(2), 193-207.

4. climate with moral behavior in youth sport: The role of social support, perspective taking, and moral disengagement. Sport, Exercise, and Performance Psychology. Advance online publication.

5. Duda, J. L. (2013). The conceptual and empirical foundations of Empowering Coaching TM: Setting the stage for the PAPA project. International Journal of Sport and Exercise Psychology, 11(4), 311-318.

6. Gano-Overway, L. A. (2013). Exploring the connections between caring and social behaviors in physical education. Research Quarterly for Exercise and Sport, 84, 104-114. DOI:10.1080/02701367.2013.762322

7. Hodge, K., \& Gucciardi, D. F. (2011). Prosocial and antisocial behavior in sport: The role of coaching style, autonomous vs. controlled motivation, and moral disengagement. Journal of sport and exercise psychology, 33(4), 527-547.

8. Kavussanu, M., \& Boardley, I. D. (2009). The Prosocial and Antisocial Behaviour in Sport Scale. Journal of Sport \& Exercise Psychology, 31, 97-117.

9. Lee, M.J., Whitehead, J., Ntoumanis, N. and Hatzigeorgiadis, A. (2008). Relationships among values, achievement orientations, and attitudes in youth sport. Journal of Sport Exercise Psychology, 30, 588-610,

10. Rutten, E. A., Schuengel, C., Dirks, E., Stams, G. J. J., Biesta, G. J., \& Hoeksma, J. B. (2011). Predictors of antisocial and prosocial behavior in an adolescent sports context. Social Development, 20(2), 294-315,

11. Sage, L., \& Kavussanu, M. (2008). Goal orientations, motivational climate, and prosocial and antisocial behavior in youth soccer: Exploring their temporal stability and reciprocal relationships. Journal of Sports Sciences, 26, $717-732$.

12. Shields, D. L. L., \& Bredemeier, B. J. L. (1995). Character development and physical activity. Human Kinetics Publishers.

13. Siedentop, D., Hastie, P. A., \& Van der Mars, H. (2011). Complete guide to sport education. Human Kinetics.

14. Stanger, N., Backhouse, S. H., Jennings, A., \& McKenna, J. (2018). Linking motivational

15. Stephens, D. E., \& Bredemeier, B. J. L. (1996). Moral atmosphere and judgments about aggression in girls' soccer: Relationships among moral and motivational variables. Journal of Sport and Exercise Psychology, 18(2), 158-173, 